\title{
Atatürk ve Ondokuz Mayıs Üniversitesi Diş Hekimliği Fakültesi Klinik Öğrencilerinin HIV/AIDS Bilgi Düzeylerinin Karşılaştırılması
}

\author{
Okan Karalar(0000-0001-7650-975X) ${ }^{\alpha}$, Nuran Yanıkoğlu(0000-0001-7677-1248) ${ }^{\alpha}$, Gözlem Ceylan(0000-0003-1257-803X) ${ }^{\beta}$, \\ Rafat Sasany(0000-0001-9321-1031) ${ }^{\beta}$, Esra Çınar Tanrıverdi (0000-0001-8857-3986) ${ }^{\gamma}$
}

Selcuk Dent J, 2021; 8: 443-452 (Doi: 10.15311/selcukdentj.690860)

Basvuru Tarihi: 25 Subat 2020 Yayına Kabul Tarihi: 10 Aralık 2020

öz

Atatürk Ve Ondokuz Mayıs Üniversitesi Diş Hekimliği Fakültesi Klinik Öğrencilerinin HIV/AIDS Bilgi Düzeylerinin Karşılaştırıması

Amaç: Bu çalışmanın amacı, Atatürk ve Ondokuz Mayıs Üniversitesi Diş Hekimliği Fakültesi klinik öğrencilerinin İnsan İmmün Yetmezlik Virüsü (HIV) ve Edinsel Bağışıklık Yetersizliği Sendromu (AIDS) hakkındaki bilgi düzeylerini karşılaşırmalı olarak değerlendirmektir.

Gereç ve Yöntemler: Diş hekimliği öğrencilerinin HIV / AIDS'e karşı farkındalık ve tutumlarını değerlendirmek için 10 sorudan oluşan bir anket hazırland. Öğrencilerle yüz yüze görüşmeler yapılarak veriler toplandı. Tanımlayıcı tipte düzenlenen bu araştırma, 01 Temmuz - 31 Aralık 2019 tarihleri arasında Atatürk ve Ondokuz Mayıs Üniversitesi öğrencileri üzerinde yapılmıştır. Öğrencilerin HIV / AIDS'e karşı farkındalık ve tutumlarını değerlendirmek amacıyla, çoktan seçmeli ve boşluk doldurmalı sorulardan oluşan, anket formu kullanıımışır. Elde edilen verilerin istatistiksel analizi ki-kare karşılaştırma testleri kullanılarak yapıldı; $p<0.05$ değeri istatistiksel olarak anlamlı kabul edildi.

Bulgular: Tüm katılımcılar arasında farkındalık düzeyi daha yüksek olmakla birlikte 4 . sını öğrencilerinin 5 . sınıfa göre daha az bilgiye sahip olduğu görülmüştür $(p<0.05)$. Her iki üniversite öğrencisi tarafından verilen cevaplar arasında anlamlı bir fark yoktur $(p>0.05)$. Ondokuz Mayıs Üniversitesi'nde yapılan ankette AIDS komplikasyonları sorusuna 4 . sınıfın \% 48'i ve 5 . sınıfın \% 73'ü doğru cevap vermiştir. Atatürk Üniversitesi'nde yapılan ankette, HIV veya HIV virüsünün AIDS'ten izole edilebileceği sorusunda 4 . sınıf öğrencilerinden $\% 70,5$. sınıf öğrencilerinden \% 84 oranında sperm yanıtı alınmıştır.

Sonuç: Çoğu öğrencinin HIV/AIDS'in nasıl bulaştığı konusunda yetersiz kaldıkları ve HIV/AIDS konusunda bilgi ve kaynak eksikliğinin yanlışığı tetiklediği sonucuna varılmıştır. Bu bulgulara göre, özellikle klinik öğrencileri için HIV/AIDS hastalarına olumlu tutumlar oluşturmak için etkili eğitim programları hazırlanmalıdır.

\section{ANAHTAR KELIMELER}

AIDS, Diş hekimliği fakültesi öğrencileri, Farkındalık düzeyi, HIV

Ülkemizde HIV ile enfekte vaka sayılarının artma nedenleri; toplumun HIV/AIDS konusunda bilgi ve bilinç düzeyinin düşük olması, cinsel yolla bulaşan enfeksiyonlar konusunda bilgi kısıtlılı̆̆, genç nüfusa (15-49 yaş) sahip olmak, nüfus hareketliliği, turizm

\section{ABSTRACT}

Comparison of The Knowledge of Atatürk and Ondokuz Mayıs University Dental Clinical Students About HIV/AIDS

Background: The aim of this study is to evaluate the knowledge levels of Atatürk and Ondokuz Mayıs University Faculty of Dentistry clinical students about Human Immunodeficiency Virus (HIV) and Acquired Immune Deficiency Syndrome (AIDS) comparatively.

Methods: A questionnaire consisting of 10 questions was prepared to evaluate the dentistry students' awareness and attitudes towards HIV / AIDS. The data were collected through face-to-face interviews with the students. This descriptive study was conducted on Atatürk and Ondokuz Mayıs University students between 01 July - 31 December 2019. In order to evaluate the students' awareness and attitudes towards HIV / AIDS, a questionnaire form consisting of multiple choice and fillin-the-blank questions was used. Statistical analysis of the data obtained was made using chi-square comparison tests; A value of $p<0.05$ was considered statistically significant.

Results: Although the level of awareness was higher among all participants, it was observed that grade 4 students had less information than grade 5 students $(p<0.05)$. There was no significant difference between the answers given by both university students $(p>0.05)$. In the survey conducted at Ondokuz Mayıs University, $48 \%$ of the 4 th grade and $73 \%$ of the 5th grade answered the question about the complications of AIDS correctly. In the questionnaire in Atatürk University, in the question of whether HIV or HIV virus can be isolated from AIDS, sperm response $70 \%$ from 4 th grade students and $84 \%$ from 5 th grade students were received.

Conclusion: It is concluded that most students are inadequate about how HIV/AIDS is transmitted, and the lack of knowledge and resources on HIV/AIDS triggers inaccuracy. According to these findings, effective training programs should be prepared especially for clinical students to create positive attitudes for HIV/AIDS patients.

\section{KEYWORDS}

AIDS, Awareness Level, Dental Students, HIV

ülkesi olmak ve damar içi madde kullanımında artış olarak bildirilmektedir. ${ }^{1}$

Aile kontrolünün azalması ile birlikte, daha bağımsız yaşamaya başlayan üniversite öğrencilerinin çoğu,

\footnotetext{
${ }^{\alpha}$ Atatürk Üniversitesi Diş Hekimliği Fakültesi Protetik Diş Tedavisi AD. Erzurum, Türkiye

$\beta$ Ondokuz Mayıs Üniversitesi Diş Hekimliği Fakültesi, Protetik Diş Tedavi AD. Samsun, Türkiye

${ }^{\vee}$ Atatürk Üniversitesi Tıp Fakültesi Tıp Eğitimi AD. Erzurum, Türkiye
} 
cinsel konulara ilgi duymakta, ancak bu konuda egitim alamamaktadırlar. Bu nedenle, üniversite öğrencileri HIV/AIDS riski ile karşı karşıyadır. ${ }^{2,3}$ Literatürde HIV/AIDS ile ilgili üniversite öğrencilerinin risk altında olduğu, bu öğrencilerin bilgi durumlarının belirlenip eğitilmeleri gerektiği vurgulanmaktadır. ${ }^{4,5}$

Sağlık alanında eğitim gören öğrenciler hem içinde bulundukları yaş grubu hem de meslekleri nedeniyle HIV ile karşılaşma riski en yüksek gruplar arasında yer almaktadırlar. HIV/AIDS vakalarının artmasını engellemek adına bu risk gruplarının bilgi ve uygulamalarının değerlendirilip gerekli bilgilendirmelerin yapılması önem taşımaktadır. Konu ile ilgili ülkemizde ve dünyada çeşitli çalışmalar yapılmıştır. Toker ve ark. $^{6}$ sağlık yüksekokulu öğrencilerinin HIV/AIDS hakkındaki bilgi durumlarını değerlendirdikleri çalışmada, öğrencilerin sınıfları arttıkça bilgi düzeylerinin de anlamlı olarak arttığını, ancak HIV/AIDS açısından daha özel ve detaylı eğitime intiyaçları olduğunu belirlemişlerdir. Okumuş ve

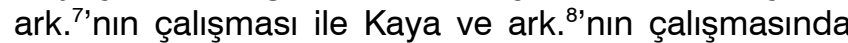
öğrencilerin öğrenim gördüğü sınıf artıkça bilgi düzeylerinin arttığı belirlenmiştir.

Hastanın, kendinin ve diğer sağlık çalışanlarının güvenliğini sağlama sorumluluğu olan diş hekimliği bölümü öğrencilerinin; hem yeni öğrenilen uygulamalar konusunda yetersizlikleri yaşamaktadırlar. Hem de hastalık bulaşmasına yönelik bilgi eksikliğinden kaynaklanan korkusuzlukları, onları kan ve kan ürünleriyle bulaşan hastalıklara karşı daha dikkatsiz davranmaya yöneltebilmektedir. Bu nedenle öğrencilerin hem kan ve vücut sıvıları ile bulaşan hastalıklar hakkında hem de bu hastalıkların bulaşma yolları hakkında bilgilendirilmesi büyük önem taşımaktadır. ${ }^{9}$

İnsan immün yetmezlik virüsü (HIV) CD4 pozitif (CD4+) T hücrelerini yok ederek bağışıklık sistemine saldırır. Edinilmiş immün yetmezlik sendromu (AIDS) ise HIV enfeksiyonunun son aşamasıdır. HIV ile enfekte kişide CD4+ sayısı progressif olarak azalır ve 200'ün altına indiğinde immün yetmezlik oluşur, bunun sonucu olarak da pnömoni veya tüberküloz gibi fırsatçı enfeksiyonlar ve bazı kanserler gelişir. ${ }^{10}$

HIV/AIDS hayat boyu süren, immün yetmezliğe neden olarak ağır fırsatçı enfeksiyon ve kanserlere yol açabilen bu nedenle sürekli antiviral ilaç kullanımı ve kontrol altında olmayı gerektiren bir enfeksiyon hastalığıdır. HIV enfeksiyonu nedeniyle dünyada her yıl 1.000.000 kişi hayatını kaybetmektedir. Sahra altı Afrika'da dakikada bir genç kIz HIV ile enfekte olmaktadır. Afrika dışı ülkelerde risk grupları seks çalışanları, homoseksüel erkekler, transseksüeller, intravenöz ilaç bağımlıları, mahkumlar ve bunların cinsel partnerleridir. ${ }^{11}$

Dünya genelinde 2018 yıl sonu itibarıyle HIV virüsü ile enfekte yaklaşık 37.9 milyon kişi olduğu ve bunların 1.7 milyonunun çocuk olduğu tahmin edilmektedir. ${ }^{12}$

Dünya genelinde seroprevalansın en yüksek olduğu kıta Afrika olup HIV/AIDS olgularının \% 22.3'ü antiretroviral tedavi alabilmektedir. Dünya genelinde seroprevalansın en yüksek olduğu bölge Afrika olup olguların Yaklaşık \% 68'i Afrika'da, \% 10'u Güney Asya'da, \% 9'u Amerika'da ve \% 6'sı Avrupa'da yaşamaktadır. ${ }^{11}$

HIV enfeksiyonu ve AIDS dünya genelinde azalmakta iken ülkemizde ve bazı ülkelerde olgu sayısı artış göstermektedir. Türkiye'deki ilk HIV vakası 1985 yılında bildirilmiştir ve yıllar içinde vakaların sayısında hızlı bir artış izlenmiştir. Ülkemizde son yıllarda hızla artarak toplam olgu sayısı 2018 yilı sonunda 21520 olarak açıklanmış olup 19.748 HIV(+) kişi ve 1772 AIDS vakası mevcuttur. Vakaların yaklaşık \% 80'i erkek, \% 20'si kadındır ve \% 15.4'ü yabancı uyruklu kişilerdir. ${ }^{13}$ Türkiye HIV/AIDS'in yayılmasına sebep olan bir dizi risk faktörüne sahiptir. Bu nedenle yukarıda belirtilen rakamların hafife alınmaması gerekmektedir. ${ }^{14}$

Dünya Sağlık Örgütü (WHO), tüm yeni enfeksiyonların \% 45'inden fazlasının 15-24 yaş arası insanlarda meydana geldiğini bildirmiştir. Türkiye, toplam nüfusun \% 19'unu oluşturan genç bir nüfusa sahiptir ve bu grup HIV/AIDS için yüksek risk altında görülmektedir. ${ }^{13}$ Heteroseksüel ilişki iletimin en yaygın yoludur. Türkiye'de HIV/AIDS enfeksiyonu vakalarının yaklaşık yüzde \% 48'inde bulaş yolu saptanamamış olup, \% 34'ü heteroseksüel, \% 14'ü homoseksüel cinsel ilişkiden ve \% 1 'i intravenöz ilaç kullanımından, \% $1^{\prime} i$ anneden bebeğe geçiş ile bulaşmıştır. ${ }^{13}$ HIV enfeksiyonu tanısı konan hastaların (136 kişi \%80 erkek, ortalama yaş 36 yıl) \% 8'ini üniversite mezunları oluşturmaktadır. HIV/AIDS'e yönelik tutumlar kültürün çeşitli yönlerinden de etkilenmektedir. Örneğin, Türk toplumunda cinsel davranış tabu konusu olarak kabul edilir ve cinsel yolla bulaşan bir hastalığa sahip olmak utanç olarak kabul edilir. ${ }^{15,16}$

HIV/AIDS hakkında sağlık eğitimi verilmesi ve hastalığın önlenmesi ile ilgili alınacak tedbirler Türkiye'de ana sağlık öncelikleri olmaya devam etmektedir. AIDS hakkında yeterli bilginin risk davranışını azaltacağı varsayılabilir. Bununla birlikte, Türkiye'de yapılan kantitatif çalışmalar, HIV/AIDS ile ilgili bilgi seviyesinin çok düşük olduğunu ileri sürmektedir. ${ }^{17,18}$

HIV enfeksiyonunu önlemek için etkili bir aşı yakın gelecekte mevcut olmayacaktır. Enfeksiyonun tedavisi hayat boyu süren antiviral ilaç kombinasyonu ile yapılmakta; ilaçlara bağlı pek çok yan etkinin yönetimi, tedaviye uyum ve maliyet gibi sorunları da beraberinde gerektirmektedir. Bununla birlikte HIV pozitif hastaların sadece \% 62'si tedaviye erişebilmekte çoğu Afrika'da olan hastalar ekonomik nedenlerle tedaviye erişememektedir. ${ }^{4}$

HIV enfeksiyonu başlıca üç yolla bulaşmaktadır: Bunlar cinsel yol, kan yolu (kan ve kan ürünleri nakli, kontamine iğne ile peruktan yaralanma) ve anneden bebeğe geçiştir. Kan ve cinsel sekresyonlar dışında virüs yükü çok düşük 
olduğundan sosyal temaslar, aynı evde yaşama, öpüşme, öksürük, klozet gibi yollarla bulaşmamaktadır. ${ }^{4}$

HIV enfeksiyonu uzun yıllar belirti vermediğinden HIV enfekte kişiler kendileri de bilmeden virüsü yıllarca özellikle cinsel partnerlerine bulaştırmaya devam etmektedirler. ${ }^{4}$

AIDS pandemisini kısıtlamak için, HIV/AIDS enfeksiyonu olasılığını azaltacak davranışlarda değişikliklere neden olmak çok önemlidir. ${ }^{19}$ Türkiye'de nüfusun üçte birinden fazlası genç bireyler olduğu için hastalığı önleme eğitim programlarının ana anahtarıdır. $^{20}$

Dental prosedürler sıklıkla kan kaynaklı patojenler ve HIV gibi mikroorganizma çeşitlerini içeren kan ve tükürüğü de kapsamaktadır. Dental tedavi prosedürleri sırasında HIV bulaşma riskinin düşük olmasına rağmen, birçok diş hekimi enfekte hastaları tedavi etmeye isteksizdir. Bu endişeler, bazı diş hekimlerinin bu hastalık hakkındaki bilgi eksikliğine dayanabilir. Bazı diş hekimleri, bu tür bir hastayla nasıl iletişim kurulacağı konusunda, enfekte olmaktan, işlerinin azalmasından ve belirsiz hissetmekten korktuğunu bildirmişlerdir. ${ }^{21}$

Diş hekimliği fakültesi öğrencileri toplumda dinamik ve yüksek eğitimli bir grubu temsil eder. Gelecekteki sağlık hizmeti sağlayıcıları olarak, bizlerin de HIV tedavisinde önemli bir rol oynaması bekleniyor. Bu nedenle, diş hekimliği fakültesi, öğrencilere HIV/AIDS ile ilgili bilgi, tutum ve becerilerini geliştirmek için çok sayıda fırsat sunmalıdır ve öğrencilerin HIV/AIDS'e yönelik bilgi ve tutumlarının ölçülmesi, diş hekimliği müfredatında HIV/AIDS eğitiminin yeterliliğini değerlendirmek için gereklidir. ${ }^{22}$

Özellikle klinik diş hekimliği öğrencileri, hastanın vücut sıvılarından AIDS başta olmak üzere çeşitli enfeksiyonların ortaya çıkabileceği birtakım hastalıklarla karşılaşabilmektedirler. Diğer bulaşıcı hastalıklarla karşılaştırıldığında, diş hekimliği öğrencilerinin HBV ve HCV ile enfekte olmuş hastaları, HIV enfeksiyonundan tedavi etmeye daha fazla istekli oldukları bulunmuştur. Diş hekimliği öğrencileri, bu hastalara etkili klinik yaklaşım sağlamak için HIV/AIDS'in önemini bilmeli ve anlamalıdırlar. Ayrıca hastalık süreci, oral bulgular ve bulaşma yolları hakkında yeterli bilgiye sahip olmaları gereklidir. Diş hekimliği öğrencilerinin ders programlarına HIV enfeksiyonları/AIDS'li hastalar hakkında vaka çalışmaları, tartı̧̧ma grupları ve yakından denetlenen klinik deneyimler gibi daha kapsamlı bir materyal eklemeyi tercih ettikleri bildirilmiştir. Tüm sağlık personelleri, diş hekimliği öğrencileri de dahil olmak üzere, HIV ile yaşayan insanlar için uygun tedavi ve bakım sağlamak için etik sorumluluğa sahiptirler.23

Bilgi, alışkanlıkların değişmesi için ön koşulu oluşturur. Sağlık davranış teorileri, bilişsel ve sosyal faktörlerin insan sağlığına ve hastalığa nasıl katkıda bulunduğu konusundaki anlayışımızı etkilemektedir. Bu çalışmanın amacı, Atatürk ve Ondokuz Mayıs Üniversitesi Diş Hekimliği Fakültesi klinik öğrencilerinin İmmün Yetmezlik Virüsü (HIV) ve Edinilmiş İmmün Yetmezlik Sendromu (AIDS) hakkındaki bilgi ve tutumlarını değerlendirmektir. Çalışmanın sıfır hipotezi; Atatürk ve Ondokuz Mayıs Üniversitesi Diş Hekimliği Fakültesi 4. ve 5. Sınıf klinik öğrencilerinin bilgi düzeyleri arasında anlamlı bir fark olmadığı şeklindedir. İkinci hipotezimiz ise, 5.sınıf klinik öğrencilerinin bilgi düzeylerinin 4. Sınıf klinik öğrencilerine göre daha fazla olduğu ve eğitim hayatı ilerledikçe öğrencilerin bilgi düzeylerinin arttığı yönündedir.

\section{GEREÇ VE YÖNTEMLER}

Çalışma Helsinki Deklerasyonu Prensipleri'ne uygun olarak yapılmıştır. Bu anket çalışması için Atatürk Üniversitesi Diş Hekimliği Fakültesi Etik Kurulu'ndan onay alınmıştır. (16/25.12.2017) Atatürk Üniversitesi ve Ondokuz Mayıs Üniversitesi Diş Hekimliği Fakülteleri 4. ve 5. sınıf öğrencilerinin HIV/AIDS'e yönelik bilgi seviyelerini, farkındalık ve tutumlarını değerlendirmek için toplam 352 öğrenci ile 10 soru içeren bir anket yapıldı. Diş hekimliği öğrencileri ile yüz yüze görüşmeler yapılarak veriler toplandı. Tanımlayıc tipte düzenlenen bu araștırma, 01 Temmuz - 31 Aralık 2019 tarihleri arasında Atatürk ve Ondokuz Mayıs Üniversitesi öğrencileri üzerinde yapılmıştır. Öğrencilerin HIV / AIDS'e karşı farkındalık ve tutumlarını değerlendirmek amacıyla, çoktan seçmeli ve boşluk doldurmalı sorulardan oluşan, anket formu kullanılmıştır.

Yapılan anketle diş hekimliği fakültesi öğrencilerinin bilgi düzeyleri ve sınıf ilerledikçe sonuçlarda pozitif değişim olup olmadığı değerlendirilmeye çalışılmıştır. (Ondokuz Mayıs Üniversitesi 4.sınıf öğrecileri 58 kişi, 5.sınıf öğrencileri 81 kişi, Atatürk üniversitesi 4. sınıf öğrencileri 127 kişi ve 5 . Sınıf öğrencileri 86 kişi) Sorular, daha önceki çalışmaların incelemesine dayanarak seçildi. Veriler öğrencilerle yüz yüze görüşmeler yapılarak toplandı. Verilerin istatistiksel analizi için ki-kare testleri kullanılmıştır. İstatistiksel olarak $p<0.05$ seviyesinde sonuçlar anlamlı olarak belirlendi.

\section{BULGULAR}

Öğrencilerin HIV/AIDS'in bulaşma yollarılyla ilgili sorulara verdikleri yanıtların sınıflara göre dağılımı Tablo 1 'de sunulmuştur. 
Tablo 1.

\section{HIV-AIDS'in bulaşmasında etkili olabilecek etmenlerle ilgili soruya verilen yanıt oranları}

\begin{tabular}{|c|c|c|c|c|c|}
\hline \multirow{2}{*}{ Sorgulanan olası bulaş yolları } & & \multicolumn{2}{|c|}{ Atatürk Ūniversitesi } & \multicolumn{2}{|c|}{$\begin{array}{l}\text { Ondokuz Mayls } \\
\text { Universitesi }\end{array}$} \\
\hline & & 4.sinif & 5.sinif & 4.sinif & 5.sinif \\
\hline $\begin{array}{l}\text { HIV virüsü tarafindan } \\
\text { herhangi bir kimse enfekte } \\
\text { edilebilir mi? }\end{array}$ & Evet & 97,7 & 96,6 & 98 & 88,8 \\
\hline \multirow{4}{*}{$\begin{array}{l}\text { Așağıdaki gruplardan HIV } \\
\text { virüsü ile enfekte olma riskine } \\
\text { sahip olanları işaretleyiniz. }\end{array}$} & Homoseksüeller & 89 & 87 & 83 & 73 \\
\hline & Narkomanlar & 81 & 86 & 61 & 66 \\
\hline & Hayat kadınları & 93 & 93 & 94 & 94 \\
\hline & $\begin{array}{l}\text { Kan nakli } \\
\text { yaptranlar }\end{array}$ & 86 & 92 & 82 & 74 \\
\hline \multirow{4}{*}{$\begin{array}{l}\text { HIV virüsünün bir bireyden } \\
\text { diğerine geçebildiği yolları } \\
\text { işaretleyiniz. }\end{array}$} & $\begin{array}{l}\text { Kan nakli } \\
\text { yaptranlar }\end{array}$ & 91 & 75 & 87 & 86 \\
\hline & $\begin{array}{l}\text { Korunmadan } \\
\text { cinsel ilişki }\end{array}$ & 96 & 95 & 95 & 90 \\
\hline & $\begin{array}{c}\text { Intravenöz } \\
\text { uyustturucu } \\
\text { kullanma }\end{array}$ & 89 & 75 & 76 & 66 \\
\hline & $\begin{array}{l}\text { Enfekte bir } \\
\text { annenin } \\
\text { çocuğunu süt ile } \\
\text { beslemesi }\end{array}$ & 46 & 31 & 43 & 50 \\
\hline \multirow{2}{*}{$\begin{array}{l}\text { HIV enfeksiyonunun tesshisi } \\
\text { için hangi metod kullanilir? }\end{array}$} & Idrar muayenesi & 40 & 15 & 3 & 5 \\
\hline & Kan muayenesi & 94 & 90 & 96 & 95 \\
\hline \multirow{4}{*}{$\begin{array}{l}\text { AIDS' lide HIV virüsünün izole } \\
\text { edilebildiği bölgeler } \\
\text { hangileridir? }\end{array}$} & Meni & 70 & 79 & 70 & 84 \\
\hline & Tükürük & 65 & 64 & 50 & 42 \\
\hline & Ter & 24 & 21 & 25 & 21 \\
\hline & Gözyaşı & 32 & 17 & 25 & 21 \\
\hline \multirow{6}{*}{$\begin{array}{l}\text { Aşağıdakilerden hangileri } \\
\text { AIDS' de komplikasyon olarak } \\
\text { ortaya çıan firsatçı } \\
\text { enfeksiyonlardır? }\end{array}$} & Pnömoni & 36 & 42 & 43 & 18 \\
\hline & Ensefalit & 17 & 40 & 33 & 24 \\
\hline & Herpes zoster & 74 & 59 & 58 & 35 \\
\hline & Sifiliz & 44 & 47 & 52 & 34 \\
\hline & Enterit & 19 & 31 & 27 & 19 \\
\hline & Pamukçuk & 48 & 73 & 40 & 50 \\
\hline
\end{tabular}

\section{ATATÜRK ÜNIVERSITESI Ve ONDOKUZ MAYIS ÜNIVERSITESI}

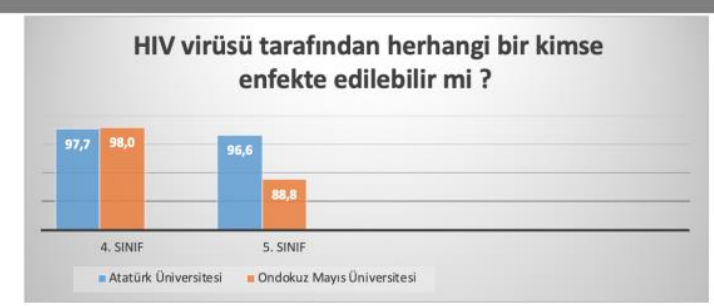

Grafik 1

HIV virüsü tarafından herhangi bir kimse enfekte edilebilir mi?

Her iki üniversitenin de 4. sınıf ve 5. sınıf öğrencilerine HIV virüsü tarafından herhangi birinin enfekte edilip edilemeyeceğinin sorulduğu soruda yüksek oranda evet cevabı verildi. (Atatürk üniversitesi öğrencileri \% 97.15 ve Ondokuz Mayıs Üniversitesi öğrencileri \% 93.4) Böylelikle ankete katılan öğrencilerin büyük bir çoğunluğunun bulaşıcı bir hastalık olduğunu düşündükleri anlaşıldı. (Grafik 1)

\section{ONDOKUZ MAYIS ÜNIVERSITES}

HIV virüsünün bir bireyden diğerine geçebildiği yolları işaretleyiniz

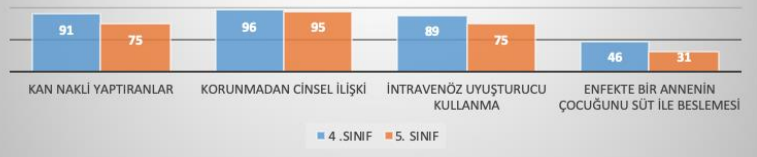

\section{ATATÜRK ÜNIVERSITESI}

HIV virüsünün bir bireyden diğerine geçebildiğ yolları işaretleyiniz

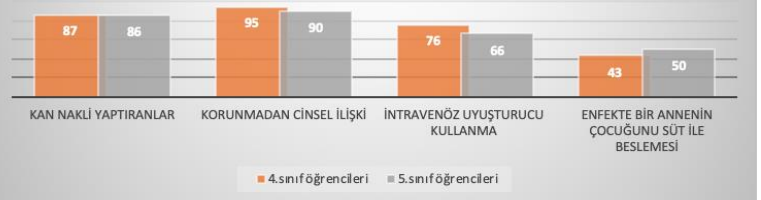

\section{Grafik 2}

HIV virüsünün bir bireyden diğerine geçebildiği yollar

Diğer bir soruda ise öğrencilere HIV virüsü ile enfekte olma riskine sahip olanlar ve HIV virüsünün bir bireyden diğerine geçebildiği yollar sorulmuştur. Bu soruda ise en yüksek orana sahip cevaplar her iki fakülte öğrencileri için de aynı olmuştur. El sıkışma, içme suyu ve gıdalar, günlük yaşamda kullanılan eşyalar, öpüşme gibi seçeneklere göre; kan nakli yaptıranlar (Atatürk üniversitesi \% 86.5, Ondokuz Mayıs Üniversitesi \% 83), korunmadan cinsel ilişki (Atatürk üniversitesi \% 92.5, Ondokuz Mayıs Üniversitesi \% 95.5), intravenöz uyuşturucu kullananlar (Atatürk üniversitesi \% 71, Ondokuz Mayıs Üniversitesi \% 82) çok daha yüksek oranda işaretlenmiştir (Grafik 2). Her iki üniversite için de bu soruda istatistiksel olarak anlamlı bir fark olmayıp birbirine paralel yanıtlar alınmıştır. $(p>0.05)$

\section{ONDOKUZ MAYIS ÜNIVERSITESI}

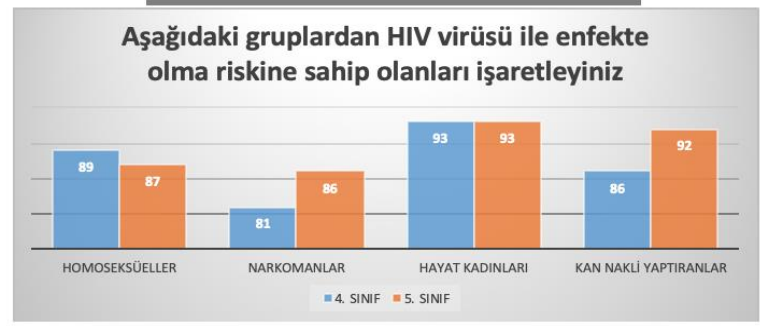

\section{ATATÜRK ÜNIVERSITESI}

Aşağıdaki gruplardan HIV virüsü ile enfekte olma riskine sahip olanları işaretleyiniz

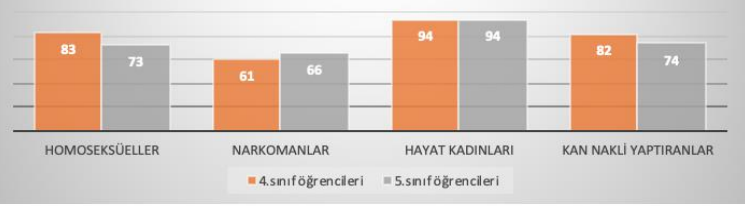

Grafik 3

HIV virüsü ile enfekte olma riskine sahip gruplar 
Öğrencilerin çoğu (\% 94), HIV enfeksiyonları için risk gruplarını doğru cevapladı. Her ne kadar sağlık çalışanları ve IV uyuşturucu kullanıcıları en yüksek risk altında görülse de, hemofili ve pıhtılaşma bozuklukları ve kan transfüzyonu olan hastalar daha az bilinmekteydi. Cinsiyet ve okul yıllarında risk grupları açısından bir fark olmamasına rağmen, beşinci sınıftaki öğrencilerin hemofili ve pıhtılaşma bozuklukları olan hastaları doğru tanıdığı ve eşcinsel erkekleri diğer gruplara göre risk grubu olarak daha iyi bildiği görülmektedir (Grafik 3).

\section{ONDOKUZ MAYIS ÜNIVERSITESI}

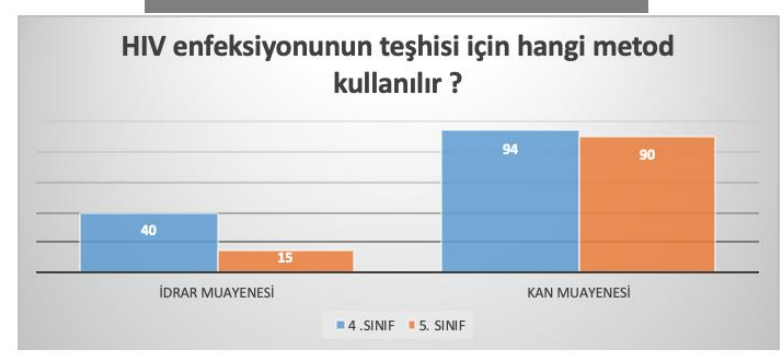

\section{ATATÜRK ÜNIVERSITESI}

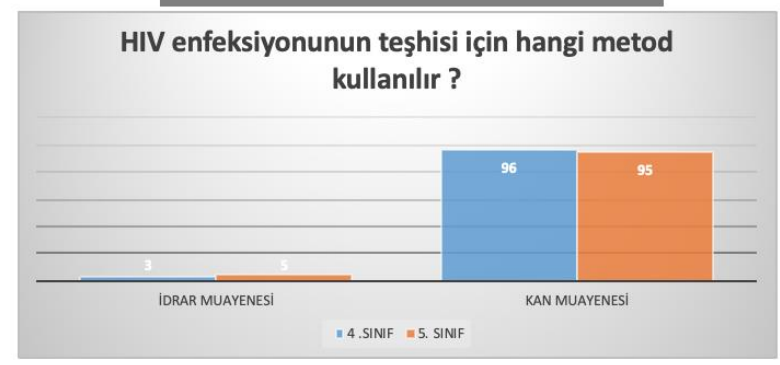

Grafik 4

HIV enfeksiyonun teşhisi için kullanılan metodlar

Öğrencilere HIV enfeksiyonun teşhisi için hangi metodun kullanıldığının sorulduğu soruda çok büyük farkla kan muayenesi idrar muayenesinden çok işaretlenmiştir. Bu soruda ayrıca her iki üniversitenin öğrencilerinin kendi aralarında 4. Sınıf ve 5. Sınıf arasında anlamlı bir fark olmadığı da görülmüştür. Hemen hemen birbirine çok yakın cevaplar verilmiştir (Atatürk Üniversitesi \% 95.5, Ondokuz Mayıs Üniversitesi \% 92) (Grafik 4).

\section{ONDOKUZ MAYIS ÜNIVERSITESI}

AIDS' lide HIV virüsünün izole edilebildiği bölgeler hangileridir?

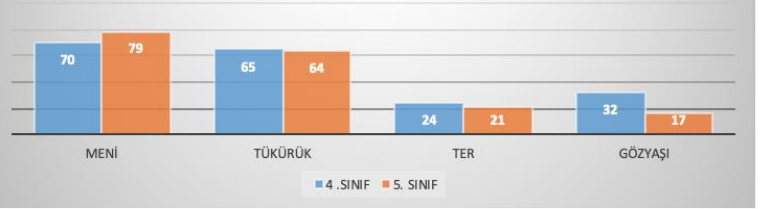

ATATÜRK ÜNIVERSITESI

AIDS' lide HIV virüsünün izole edilebildiği bölgeler hangileridir?

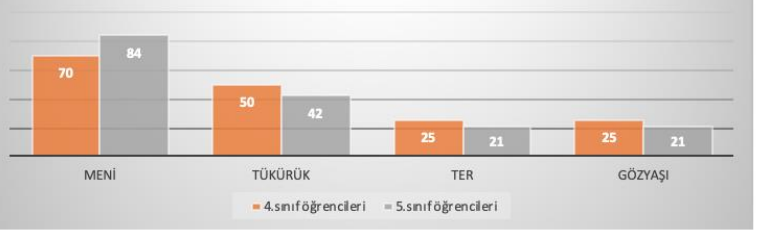

Grafik 5

AIDS' lide HIV virüsünün izole edilebildiği bölgeler

AIDS' lide HIV virüsünün izole edilebildiği bölgelerin sorulduğu anket sorusunda meni en çok işaretlenen cevaptır. (Atatürk üniversitesi \% 77 ve Ondokuz Mayıs Üniversitesi \% 74,5) Bu cevabı ise diğer şıklar olan tükürük, gözyaşı ve ter izlemiştir (Grafik 5).

\section{ONDOKUZ MAYIS ÜNIVERSITESI}

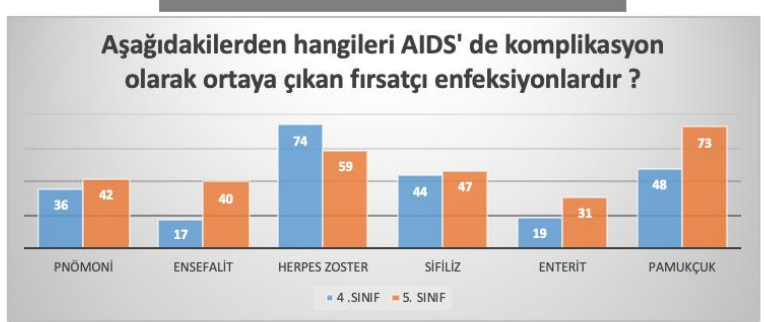

\section{ATATÜRK ÜNIVERSITESI}

Aşağıdakilerden hangileri AIDS' de komplikasyon olarak ortaya çıkan fırsatçı enfeksiyonlardır ?

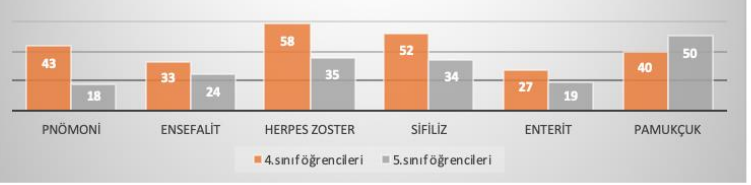

Grafik 6

AIDS'de komplikasyon olarak ortaya çıkan firsatçı enfeksiyonlar

AIDS'de ortaya çıkan fırsatçı enfeksiyonların sorulduğu soruda ise Ondokuz Mayıs Üniversitesi öğrencilerinin en çok işaretlediği şıklar Herpes Zoster (4. Sınıf öğrencileri için \% 74, 5. Sınıf öğrencileri için ise \% 59) ve pamukçuk (4.sınıf öğrencileri için \% 48, 5. Sınıf öğrencileri için ise \% 73) olup; Atatürk Üniversitesi için ise en çok işaretlenen şıklar Herpes Zoster (4. Sınıf öğrencileri için \% 58, 5. Sınıf öğrencileri için ise \% 35) ve pamukçuk (4.sınıf öğrencileri için \% 40, 5. Sınıf 
öğrencileri için ise \% 50) olmuştur. Bu açıdan bir kıyaslama yapmak gerekir ise Atatürk Üniversitesi 4. sınıf öğrencileri 5. Sınıf öğrencilerine göre konu hakkında daha doğru bilgilere sahiptirler. Ayrıca bu soruda Ondokuz Mayıs Üniversitesi öğrencileri daha yüksek oranda doğru cevap vermiştirler (Grafik 6).

\section{TARTIŞMA}

Bu çalışmada verilen cevaplar büyük çoğunluk ile birbirine paralellik göstermekle beraber anlamlı farkların bulunduğu sorular da ise öğrencilerin bu bilgileri hangi sınıflarda öğrendiği ve üzerinden ne kadar zaman geçtiğine bağlı olarak farklılıklar oluşmuştur. Teorik olarak öğrenilen bilgilerin belli bir zaman sonra yavaş yavaş unutulmaya başladığı da görülmüştür.

Atatürk ve Ondokuz Mayıs üniversitesi diş hekimliği fakültesi 4. ve 5. sınıf klinik öğrencilerinin bilgi düzeyleri arasında anlamlı bir fark olmadığı şeklindeki sıfır hipotezimiz kabul edilmiştir. 5.sınıf klinik öğrencilerinin bilgi düzeylerinin 4. Sınıf klinik öğrencilerine göre daha fazla olduğu ve eğitim hayatı ilerledikçe öğrencilerin bilgi düzeylerinin arttığı yönündeki ikinci hipotezimiz ise reddedilmiştir. Her iki sınıf arasında bilgi düzeyleri bakımından istatistiksel olarak anlamlı farklılık olmadığı görülmüştür $(p>0.05)$.

Yılmaz ve Yanıkoglu'nun ${ }^{24}$ yaptıkları çalışmaya bakıldığı zaman öğrencilerin eskiye göre sorulara daha yüksek oranda cevaplar verdiği de görülmüştür. El sıkışma gibi gündelik hayatta yapılan aktivitelerle bulaş olmadığını eskiye nazaran daha iyi anlaşıldığı görülmüştür. Ankete katılımcılar el sıkışma ile enfekte olmaya verdikleri cevap \% 100 iken, çalışmamızda ise katılımcılar bu soruya verilen cevap çok daha düşük seviyededir.

Bu çalışmanın bulguları, öğrencilerin kanla doğrudan temas etmenin tükürükten daha bulaşıcı olduğuna inandıklarını göstermiştir. Öğrencilerin 47,2'si tükürüğün diğer çalışmaların bulgularıyla uyumlu olarak AIDS' in bulaşmasında bir araç olabileceğini düşünmüştür. ${ }^{25-27}$ Diş ortamında, tükürük yoluyla bulaşmanın henüz açıklanmadığı yapılan çalışmalarda gösterilmiştir. ${ }^{27,28}$ Benzer çalışmalar, diş tedavisi sırasında aerosol solumasının, HIV ile enfekte olmuş hastaların tükürük ve kanının doğrudan kontaminasyonundan daha az etkili olduğunu göstermektedir. ${ }^{29,30}$

Ayrıca, diş hekimlerinin iki farklı üniversite hakkındaki bilgilerini karşılaştıran başka bir çalışma, HIV'in kan yoluyla bulaşmasının ortaya çıktığı gösterilmiştir.31 Bunun nedeni, bu yoldan nadir görülen HIV bulaşması raporları olabilir. ${ }^{32,33}$ Öğrencilerin çoğunluğu, kan ya da kan pıhtılaşma faktörleri yoluyla bulaşma konusunda yeterli bilgiye sahiptir (\% 99.2). Bununla birlikte, emzirme yoluyla geçiş (\% 55.6), sivrisinekler ve böcekler (\% 42.4) daha az bilinmektedir.
Öğrencilerin bilgi sorularına verdiği doğru cevap oranı ortalama \% 85.9 bulunmuştur. HIV/AIDS hakkında merak ve bilgi düzeyinin öğrenim düzeyi ile birlikte arttığını görülmüştür. Çalışmamıza denek olarak katılan öğrencilerden bilgi sorularına en yüksek oranda doğru yanıtı 5. sınıf öğrencileri vermiştir. (\% 87) 4 4.sınıf öğrencileri ise sorulara \% 84 ile doğru cevap vermişlerdir.

HIV/AIDS'e daha fazla dikkat çekilmesi ve eğitimde bunun öneminin vurgulanması gerekmektedir. Soru bazında bakıldığında HIV enfeksiyonunun ilk evrelerinde görülen semptomlar ile ilgili soru en az oranda doğru yanıtlanmıştır. $(\% 73,1)$ İnsanların günlük yaşamda birbirleriyle iç içe bir ortamda çok bulunmalarından dolayı bu konudaki yanlış bilgiler; hastaların dışlanması ve toplumdan soyutlanması gibi istenmeyen sonuçlar doğurabilir. Toplumun her yaş grubunun HIV/AIDS hakkında bilgi düzeyinin artırılması önemlidir. Bu sonuçlar öğrencilerin HIV/AIDS hakkındaki bilgi düzeyinin iyi seviyede olduğunu göstermektedir. Ancak sahip olunan doğru bilgi oranının tutum ve davranışlara yeteri kadar yansımadığı görülmüştür. HIV/AIDS hakkındaki bilgi düzeyinin daha yüksek seviyeye çıkarılması, tutum ve davranışlardaki yanlışlıkların giderilmesi ve bilinç düzeyinin artması için konuyla ilgili olarak her türlü eğitim aracının faydalı olduğu kanaatine varılmıştır.

HIV/AIDS hakkında ek bilgiye intiyaç olup olmadığını, seçim nedeninin olup olmadığını belirlemeyi amaçladık. Diş hekimliği öğrencilerinin HIV / AIDS risk grubunu doğru bir şekilde tanımaları önemlidir. Çalışmamızda, öğrencilerin HIV / AIDS risk grupları hakkında bilgi düzeyinin çok yüksek olduğu belirlenmiştir. Diş hekimliği öğrencileri diş tedavisi prosedürleri sırasında tükürük ve kan bulaşma riski altındadır. Bu nedenle sterilizasyon prosedürleri, çapraz enfeksiyonlar ve bariyer teknikleri hakkında yeterli bilgiye sahip olmalıdırlar.

Diğer çalışmalarda da benzer bulgular bildirilmiştir. ${ }^{30-33}$ Klinik öncesi ve 5 . sınıf öğrencileri emzirme yoluyla bulaşma konusunda 3 . ve 4 . sınıf öğrencilerine göre daha doğru bilgiler göstermiştir. Aslında, emzirme bebeklerde HIV enfeksiyonlarına neden olan ana sebep olabilir. ${ }^{30}$

Bu bulgular, Nijerya Diş Hekimliği Okulu'nun geçen yıl öğrencilerinin HIV bulaşma yolları hakkında daha iyi bilgi sahibi olduklarını gösteren Ajayi ve ark.29'nin çalışması ile tutarlıdır.29 Öğrencilerin çoğu (\% 82.8) ELISA olarak doğru cevap vermiş, öğrencilerin sadece \% 32.8' i doğru partikül aglütinasyon testine cevap vermiştir. Western Blot analizi (\% 57.6) ve immünofloresan (\% 44) tarama/doğrulama testleri olarak daha az tanınmışıı. Ağız boşluğunda meydana gelen ilk HIV enfeksiyonu belirtileri nedeniyle, diş hekimlerinin hastalı̆ı̆ teşhis etme olasılığı yüksektir ve bu da erken tedaviye imkan tanır. 
Çalışmamızda; katılımcıların çoğunluğu, oral kandidiyazis (\% 86.9), majör aftöz (\% 60.4) ve herpes simpleks (\% 56.4) gibi HIV ile ilişkili oral lezyonlara cevap verirken, kondiloma (\% 35.2) ve kserostomi (\% 34) gibi durumlar daha az biliniyordu. Kserostomi hariç, bu bulgular önceki bir çalışmayla karşılaştırılabilir. ${ }^{27}$ HIV ve oral kandidiyazis arasındaki ilişki Al-Naimi ve ark.34 tarafından bildirilenden daha yüksekken, Bindal ve ark. ${ }^{35}$ tarafından bildirilenden düşüktü. Dördüncü ve beşinci sınıf öğrencilerinin sözlü kandidiyazis ve ANUG konusundaki bilgileri birinci, ikinci ve üçüncü sınıf öğrencilerinden daha yüksekti. $\mathrm{Bu}$, bu yıllarda HIV / AIDS'in oral semptomları hakkındaki teorik derslerden dolayı olabilir. Mevcut bulgular, eğitim yılı seviyesi arttıkça, AIDS'in sözlü belirtileri hakkındaki bilgilerin de arttığını göstermiştir. Diş hekimliği öğrencileri, kondiloma, verruca vulgaris, tükürük bezi enfeksiyonları, liken planus ve kserostomi gibi HIV ile ilişkili lezyonlar hakkında bilgi sahibi olmuştur. Bu çalışmada, öğrencilerin dersleri HIV / AIDS ile ilgili en sık bildirilen bilgi kaynaklarıdır. Birinci sınıf öğrencileri medyadan ve gazetelerden diğerlerinden daha fazla bilgi aldı. Sonuçlarımız Nasir ve ark. ${ }^{36}$ sonuçları ile uyumlu idi. Ajayi ve ark. ${ }^{29}$ tarafından yapılan çalışmada, temel bilgi kaynakları sağlık çalışanları ve HIV / AIDS ile ilgili ders kitapları, oysa Grover ve ark. ${ }^{37}$ tarafından yapılan bir başka çalışmada elektronik medya ana kaynak olmuştur. Bilgi kaynağı olarak medya ve TV oranının yüksek olması, kaynakların kalitesi sorgulanabilirken bilgilerini geliştirmek anlamına gelmez. Ankete katılanların çoğunluğu, her hastanın potansiyel olarak bulaşıcı olarak düşünülmesi gerektiğine inanıyordu. Bu yüzdeler diğerleri tarafından bildirilenlerden daha yüksektir. ${ }^{27,38}$

Sağlık alanında eğitim gören öğrenciler hem içinde bulundukları yaş grubu hem de meslekleri nedeniyle HIV ile karşılaşma riski en yüksek gruplar arasında yer almaktadırlar. HIV/AIDS vakalarının artmasını engellemek adına bu risk gruplarının bilgi ve uygulamalarının değerlendirilip gerekli bilgilendirmelerin yapılması önem taşımaktadır. Konu ile ilgili ülkemizde ve dünyada çeşitli çalışmalar yapılmıştır. Toker ve ark. ${ }^{6}$ bir sağlık yüksekokulu öğrencilerinin HIV/AIDS hakkındaki bilgi durumlarını değerlendirdikleri çalışmada, öğrencilerin sınıfları arttıkça bilgi düzeylerinin de anlamlı olarak arttığını, ancak HIV/AIDS açısından daha özel ve detaylı eğitime intiyaçları olduğunu belirlemişlerdir. Okumuş ve ark. ${ }^{7}$ ile Kaya ve ark. ${ }^{8}$ çalışmalarında öğrencilerin öğrenim gördüğü sınıf arttıkça bilgi düzeylerinin arttığı belirlenmiştir.

Verilen cevaplar büyük çoğunluk ile birbirine paralellik göstermekle beraber anlamlı farkların bulunduğu sorular da ise öğrencilerin bu bilgileri hangi sınıflarda öğrendiği ve üzerinden ne kadar zaman geçtiğine bağlı olarak farklılıklar oluşmuştur. Teorik olarak öğrenilen bilgilerin belli bir zaman sonra yavaş yavaş unutulmaya başladığı da görülmüştür.

Öğrencilerin enfeksiyon kontrol seviyelerinden emin olmaları durumunda, kendilerini bu hastaları tedavi etmek için uygun şekilde hazırlarlar. Bu çalışmada, ankete katılanların çoğu hastaları tarafından enfekte olmaktan korkuyor olsada, neredeyse yarısı HIV hastalarının diş sağlığını güvenli bir şekilde sağlayabileceklerini belirtmişlerdir. Öğrencilerin HIV hastalarını tedavi etme istekleri, diğer çalışmaların bulgularıyla tutarlıydı. ${ }^{35,39,40} \mathrm{Bu}$ sonuçlar, Fotedar ve ark. ${ }^{41}$ ile Turhan ve ark.42, AIDS taşıyıcı sınıf arkadaşına katılmak istemeyen diş öğrenci sayısının anlamlı derecede yüksek olduğunu bildirmiştir; ancak aynı öğrenciler, AIDS'li hastaları profesyonel yaşamlarında tedavi edeceklerini bildirdi. Mevcut yasalara göre, diş hekimi HIV bulaşmış bir hastaya diş bakımı sağlamalıdır. ${ }^{25,28}$ HIV bulaş riskinin fazla tahmin edilmesi HIV hastalarına diş bakımı sağlama korkusunun en önemli nedeni gibi görünmektedir. ${ }^{39} \mathrm{Bu}$ korkular yetersizliğe neden olabilir. HIV bulaşmış hastaların tedavisini yerine getirilmeli. ${ }^{43}$ Yeterli bilgi ve olumlu tutum HIV / AIDS hastalarını tedavi etmenin ana kriterleridir. Araştırmalar, bilgi arttıkça HIV / AIDS hastalarını tedavi etme istekliliğini arttırdıklarını göstermiştir. ${ }^{28,32,38,43}$

Çalışmamızda öğrencilerin\% 28,4'ü HIV hastalarına CPR yapabileceklerini ve daha fazla erkek öğrencinin CPR yapma konusunda kendinden emin olduklarını bildirdi. Bu sonuçlar diğerleri tarafından bildirilenlerden çok daha yüksektir. ${ }^{25,38}$

\section{SONUÇ}

$\mathrm{Bu}$ çalışmanın sonuçları öğrencilerin çoğunluğunun HIV/AIDS hakkındaki bilgi ve eğitim seviyelerinin yeterli olmadığını ve daha fazla eğitime intiyaç duyduklarını göstermiştir. Beşinci sınıf öğrencilerinin çoğu HIV/AIDS hakkındaki bilgi ve eğitim seviyelerinin diğerlerine göre yeterli olduğunu bildirmiştir. Diş hekimliği öğrencilerinin HIV/AIDS hastalarının tedavisinin yönetimi hakkındaki bilgilerinden emin olmaları durumunda, kendilerini bu hastaları tedavi etmeye hazır olabileceklerini düşünüyorlar.

$\mathrm{Bu}$ çalışmada öğrencilerin HIV ile ilgili bilgi düzeyleri kabul edilebilir. Bununla birlikte, öğrenciler HIV/AIDS' in bulaşmasının ve kontrolünün önemli bir kısmı hakkında bilgi sahibi değildir. Bu eksiklikler klinik öncesi öğrencilerde daha sık gözlendi. Öğrencinin HIV pozitif hastaları tedavi etmeye istekli olduğu göz önüne alındığında, tatmin edici değildir.

Öğrencilerin bu bulaşıcı hastalıklar hakkında iyi bilgilendirilmeleri ve bu hastaları tedavi etmeye yönelik gerekli güvenli pratik becerileri ve olumlu tutum geliştirmeleri gerekir. Diş hekimlerinin HIV'li hastalara yönelik olumsuz tutumları, HIV bulaşmış kişilerin diş sağlığını etkileyebilir. Ayrıca, bulgularımız HIV enfeksiyonu bilgisi ile ilgili müfredatın ilk yıldan 
ile ilgili müfredatın ilk yıldan başlayarak ve klinik yıllarda da devam ettirilmesi ve dikkatle incelenmesi ve iyileştirilmesi gerektiğini göstermiştir. Enfeksiyon kontrol prosedürleriyle ilgili eğitim özellikle klinik öncesi öğrenciler için arttırımalıdır. Gelecekte, bu tür hastaların tedavisine yönelik bilgi ve olumlu tutum ile iyi donanımlı diş hekimleri hazırlamak için, yaralanmaları önleme konusundaki farkındalıklarını geliştirmek ve evrensel önlem ve bu enfeksiyonlara ilişkin risk algılarını değerlendirmek için sağlık eğitimi programı önerilmektedir. 


\section{KAYNAKLAR}

1. 14 Kasım $2019 \quad$ Tarihinde http://www.hatam.hacettepe.edu.tr/94/01.pdf. adresinden erişildi.

2. Wang B, Li X, Stanton B, Fang X, Liang G, Liu H, et al. Gender differences in HIV-related perceptions, sexual risk behaviors, and history of sexually transmitted diseases among Chinese migrants visiting public sexually transmitted disease clinics. AIDS Patient Care STDS 2007;21(1):57-68.

3. Yang H, Li X, Stanton B, Fang X, Lin D, Naar-King S. HIV-related knowledge, stigma, and willingness to disclose: A mediation analysis. AIDS Care 2006;18(7):717-24.

4. 2008" Ddnkr. 25 Eylül 2019 Tarihinde http://whqlibdoc.who.int/publications/2009/978928320 4237_tur_p1-104.pdf. adresinden erişildi.

5. Nwokocha AR, Nwakoby BA. Knowledge, attitude, and behavior of secondary (high) school students concerning HIV/AIDS in Enugu, Nigeria, in the year 2000. J Pediatr Adolesc Gynecol 2002;15(2):93-6.

6. Toker SO, Küçükyılmaz Ü. Ege Üniversitesi Ödemiş Sağlik Yüksekokulu Öğrencilerinin Hıv/Aıds Bilgi Düzeylerinin Eğitim Öncesi Ve Sonrasında Değerlendirilmesi. Ege Tıp Dergisi 2001;40(2):91-7.

7. Okumuş $H$, Mete $S$, Uysal ÜE. Hemşirelerin AiDS'e ilişkin Bilgi ve Tutumları. AIDS Dergisi 1996;3(6):52.

8. Kaya E, Akıllı M, Sezek F. Lise öğrencilerinin hiv/aids konusundaki bilgi düzeylerinin farklı değişkenler açısından incelenmesi. Pamukkale Üni Eğitim Fak Derg 2010; 27(27):139-45.

9. Kurt AS, Yılmaz SD. Sağlık yüksekokulu öğrencilerinin HIV/AIDS hakkındaki bilgi düzeyleri ve bilgi kaynakları. Hemşirelikte Eğitim ve Araştırma 2012;9(3):47-52.

10.Okay G, Şengöz G. HIV/AIDS hastalarında ELISA yöntemi ile Cryptosporidium türlerinin sıklığının araştırıması. Balıkesir Medical Journal 2006;2(1):7082.

11.WHO. HIV/AIDS Data and Statistics. 2 Ekim 2019 Tarihinde https://www.who.int/hiv/data/en/ adresinden erişildi.

12.Epidemic. TGHA. 2 Ekim 2019 Tarihinde https://www.hiv.gov/hiv-basics/overview/data-andtrends/global-statistics adresinden erişildi.

13. Bakanlığı TCS. Türkiye HIV/AIDS Kontrol Programı (2019-2024).

14.Aksu O. Ayrımcılığın özel bir alanı: HIV Pozitif kadınlar ve çalışma hayatı. AUAd 2017;3(4):174-86

15. Kasapoğlu A, Çabuk Kaya N, Turan F, Kuş E. Vulnerability Assessment of People Living with HIV (PLHIV) in Turkey. 2007.

16. Ungan M, Yaman H. AIDS knowledge and educational needs of technical university students in Turkey. Patient Educ Couns 2003;51(2):163-7.

17. Acaroglu R. Knowledge and attitudes of mariners about AIDS in Turkey. J Assoc Nurses AIDS Care 2007;18(1):48-55.

18.Duyan V, Yildirim G. A brief picture of HIV/AIDS in Turkey. AIDS Patient Care STDS 2003;17(8):373-5.
19. Izdebski Z, Malecka A. Attitudes \& Opinions of youth concerning HIV/AIDS problem. HIV \& AIDS Review. Youth Counselling and Sex Education Center, Poland 2003; 2:115-22.

20. Bandura A. Health promotion by social cognitive means. Health education \& behavior, 2004;31(2):143-64.

21.Külekçi G. Dişhekimliğinde Bulaşıcı Meslek Hastalıkları-Occupatıonal Infectıous Diseases In Dentıstry. J Istanb Univ Fac Dent 1990;24(4):191-3.

22.Akpınar A, Çalışır M, Karakan C, Doğan SSA, Çınar Z. Cumhuriyet Üniversitesi Diş Hekimliği Fakültesine Başvuran Hastalarda Hepatit $B, C$ ve Hıv Görülme Sıklığı ve Farkındalığın Değerlendirilmesi. Atatürk Üniv Diş Hek Fak Derg 2017;27(2):63-6.

23. Altındiş A, Cumhur A, Kahraman EP, Köseoğlu M. Diş Hekimliği Fakültesi Öğrencilerinin Enfeksiyon Kontrolü Konusundaki Farkındalıkları ve Tutumlarının Değerlendirilmesi. Journal Of Biotechnology And Strategic Health Research, 2018;2(3):196-204.

24. Yıımaz AB, Yanıkoğlu N, Ceylan G. Atatürk Üniversitesi Dişhekimliği Fakültesi Preklinik Ve Klinik Öğrencilerinin Hıv Virüsü Ve Aıds İle İlgili Bilgi Seviyelerinin İncelenmesi. Atatürk Üniv Diş Hek Fak Derg 1997;7(1):40-3.

25.Sadeghi M, Hakimi H. Iranian dental students' knowledge of and attitudes towards HIV/AIDS patients. J Dent Educ 2009;73(6):740-5.

26. Kemppamen JK, Dubbert PM, Williams PM. Effects of group discussion and guided patient care experience on nurses' attitudes towards care of patients with AIDS. Journal of Advanced Nursing 1996;24(2):296-302.

27.Alsamghan AS. Knowledge and attitude of male dental students toward HIV/AIDS in King Khalid University, Saudi Arabia. Int J Public Health 2012;1(1):1-9.

28. McCarthy GM, Koval JJ, MacDonald JK. Factors associated with refusal to treat HIV-infected patients: the results of a national survey of dentists in Canada. Am J Public Health 1999;89(4):541-5.

29. Ajayi Y, Ajayi E. Dental students' knowledge of human immunodeficiency virus. $J$ Dent 2008;36(5):374-8.

30.Ellepola AN, Sundaram DB, Jayathilake S, Joseph BK, Sharma PN. Knowledge and attitudes about HIV/AIDS of dental students from Kuwait and Sri Lanka. J Dent Educ 2011;75(4):574-81.

31. Oberoi SS, Marya CM, Sharma N, Mohanty V, Marwah M, Oberoi A. Knowledge and attitude of Indian clinical dental students towards the dental treatment of patients with human immunodeficiency virus (HIV)/acquired immunedeficiency syndrome (AIDS). Int Dent $\mathrm{J}$ 2014;64(6):324-32. 
32. Oliveira ER, Narendran S, Falcao A. Brazilian dental students' knowledge and attitudes towards HIV infection. AIDS care 2002;14(4):569-76.

33. Blignaut $\mathrm{E}$. The role of the dental profession in the AIDS epidemic. J Dent Assoc S Afr 1994;49(3): 133-5.

34.Al-Saygh GD, Al-Naimi RJ. Knowledge, attitude and health behavior of dental students towards HIV patients. Al-Rafidain Dent J 2009;9(13):110-9.

35.Bindal P, Bindal U, Safi SZ, Hussain K, Radzi A, Safwan H. Dental Students' Perceptions on patients with HIV or Hepatitis B infection. Annu Res Rev Biol 2014;4(24):3645-55.

36. Nasir EF, Åstrøm AN, David J, Ali RW. HIV and AIDS related knowledge, sources of information, and reported need for further education among dental students in Sudan-a cross sectional study. BMC Public Health 2008;8(1):286.

37. Grover N, Prakash A, Singh S, Singh N, Singh P, Nazeer J. Attitude and knowledge of dental students of National Capital Region regarding HIV and AIDS. J Oral Maxillofac Pathol 2014;18(1):9-13.

38. Aggarwal A, Panat SR. Knowledge, attitude, and behavior in managing patients with HIV/AIDS among a group of Indian dental students. J Dent Educ 2013;77(9):1209-17.

39. Hu S-W, Lai H-R, Liao P-H. Comparing dental students' knowledge of and attitudes toward hepatitis B virus-, hepatitis C virus-, and HIV-infected patients in Taiwan. AIDS Patient Care STDS 2004;18(10):587-93.

40. Oboro H, Azodo C, Sede M. Perception of HIV/AIDS patients among pre-clinical dental students. Int J Infect Dis 2008;12(1):158.

41. Fotedar S, Sharma KR, Sogi GM, Fotedar V, Chauhan A. Knowledge and attitudes about HIV/AIDS of students in HP Government Dental College and Hospital, Shimla, India. J Dent Educ 2013;77(9):121824.

42.Turhan O, Senol Y, Baykul T, Saba R, Yalçin A. Knowledge, attitudes and behaviour of students from a medicine faculty, dentistry faculty, and medical technology Vocational Training School toward HIV/AIDS. Int J Occup Med Environ Health 2010;23(2):153-60.

43.Erasmus S, Luiters S, Brijlal P. Oral Hygiene and dental student's knowledge, attitude and behaviour in managing HIV/AIDS patients Int $J$ Dent Hyg 2005;3(4):213-7.

\section{Yazışma Adresi:}

Okan KARALAR

Atatürk Üniversitesi

Diş Hekimliği Fakültesi

Protetik Diş Tedavisi AD.

Erzurum, Türkiye

Tel : +905054167414

E Posta:karalaro@hotmail.com 